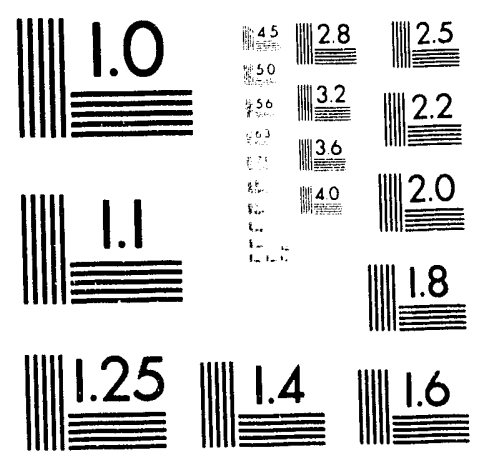



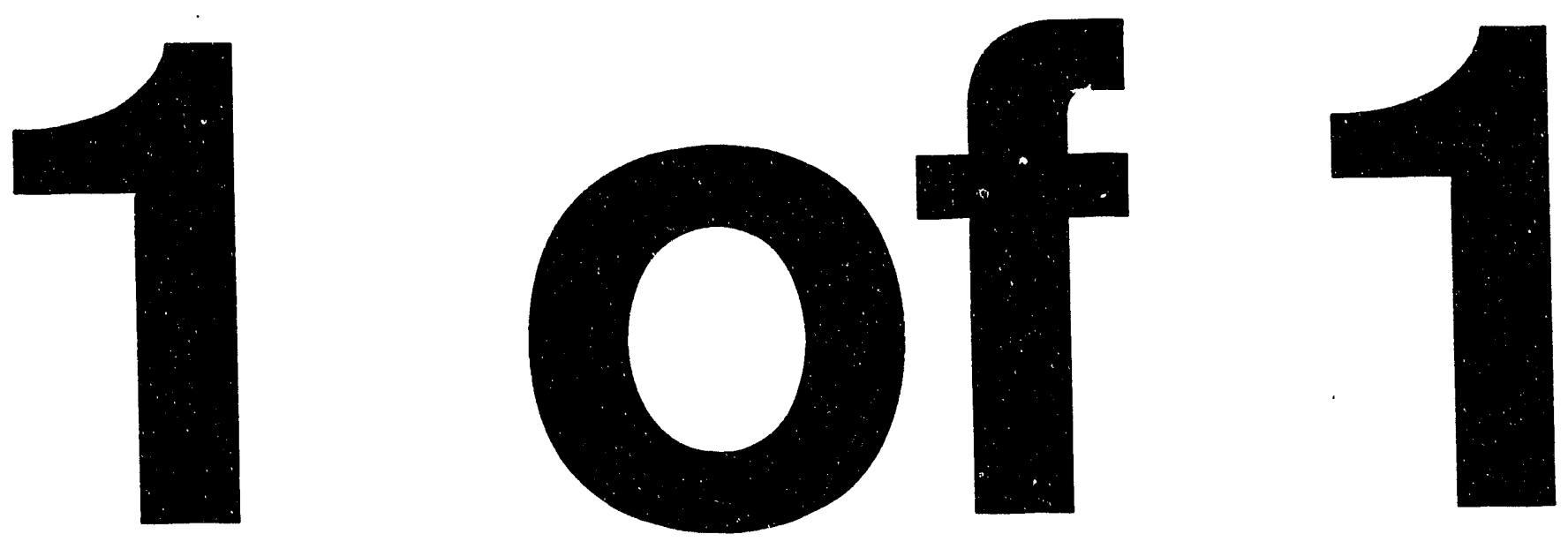

(TOKAMAK FUSION TEST REACTOR) SUPERSHOT PLASMAS \\ M.W. KISSICK, P.C. EFTHIMION, D.K. MANSFIELD, ET AL. \\ BY \\ D.K. MANSFIELD, ET AL.
}

$\sqrt{3}$ 


\section{NOTICE}

This report was prepared as an account of work sponsored by an agency of the United States Government. Neither the United States Government nor any agency thereof, nor any of their employees, makes any warranty, express or implied, or assumes any legal liability or responsibility for the accuracy, completeness, or usefulness of any information, apparatus, product, or process disclosed, or represents that its use would not infringe privately owned rights. Reference herein to any specific commercial produce, process, or service by trade name, trademark, manufacturer, or otherwise, does not necessarily constitute or imply its endorsement, recommendation, or favoring by the United States Government or any agency thereof. The views and opinions of authors expressed herein do not necessarily state or reflect those of the United States Government or any agency thereof.

\section{NOTICE}

This report has been reproduced from the best available copy.

Available in paper copy and microfiche.

Number of pages in this report: 18

DOE and DOE contractors can obtain copies of this report from:

Office of Scientific and Technical Information

P.O. Box 62

Oak Ridge, TN 37831 ;

(615) 576-8401.

This report is publicly available from the:

National Technical Information Service

Department of Commerce

5285 Port Royal Road

Springfield, Virginia 22161

(703) $487-4650$ 


\title{
Dominanc? of Convective Heat Transport in the Core of TFTR (Tokamak Fusion Test Reactor) Supershot Plasmas
}

\author{
M. W. Kissick*, P. C. Efthimion, D. K. Mansfield, J. D. Callen*, \\ C. E. Bush, H. K. Park, J. Schivell, E. J. Synakowski, G. Taylor
}

Princeton Plasma Physics Laboratory, Princeton University, $P . O$. Box 451 , Princeton, NJ 08543

\begin{abstract}
Using perturbations in electron density and temperature induced by small Helium gas puffs in TFTR (Tokamak Fusion Test Reactor) [Plasma Phys.

Controlled Nuc. Fus. Research 1, 51 (1986)], the dominance of convective heat transport in the core $(r / a<0.4)$ of supershot plasmas has been demonstrated in a new way. The TRANSP [Journal Comp. Phys. 43, 61 (1981)] transport code was used to calculate the time-dependent particle and heat fluxes. Perturbations in the calculated convective and total electron heat fluxes were compared. They demonstrate that the conductive component decreases moving into the supershot core, and the convective component dominates in the supershot core. These results suggest a different transport drive in the supershot core compared to that in the rest of the supershot plasma.
\end{abstract}

PACS: 52.25.Fi, 52.55.Fa, 52.25.Vy

*permanent address: University of Wisconsin, Madison, WI 53706-1687

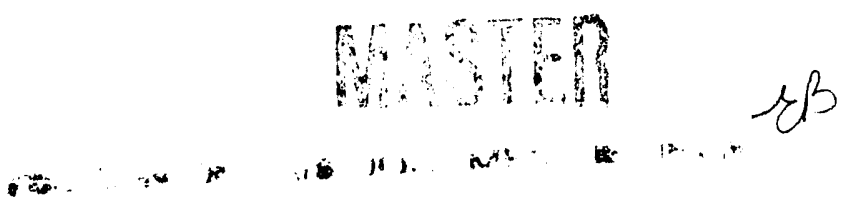




\section{Introduction}

The supershot is an enhanced confinement regime in TFTR ${ }^{1}$ (Tokamak Fusion Test Reactor) that is associated with peaked density profiles. In addition to supershot confinement being independent of $I_{p}$ and $P_{i n j}, 2,3$ it has been inferred that supershots exhibit a high degree of convective heat transport in the core region. 2.4 We have a new method for demonstrating this convective heat transport dominance in the core region by using perturbation techniques. Previous analyses inferred this convective dominance in the core of supershot plasmas using "equilibrium" (long-time) results from interpretive transport codes such as the TRANSP5 (1.5-D timedependent) code. 2,4 In this study, we used perturbations in the TRANSP calculated electron heat and particle fluxes to observe this convective dominance in the cores of an ensemble of "identical" supershots. These perturbations were caused by small gas puffs ( 3.5 torr liters over 0.02 seconds) of Helium from which small perturbations in electron temperature and density propagated inward. 3

\section{Measurement of Convective Domination}

The He was puffed during energetic neutral beam injection (13MW of balanced co- and counter- tangential injection) from a single valve located on the top of the torus. The TRANSP code was used to calculate the energy and particle balance equations from the average of 6 reproducible shots on TFTR with the following basic parameters: $R_{0}=2.45 \mathrm{~m}, a=0.80 \mathrm{~m}, \mathrm{BT}=4.8 \mathrm{~T}, \mathrm{I}_{\mathrm{p}}=1.0 \mathrm{MA}, \mathrm{q}_{a}(\mathrm{c} y \mathrm{l})=$.6 , $\mathrm{T}_{\mathrm{e}}(0)=6.5 \mathrm{keV}, \mathrm{n}_{\mathrm{e}}(0)=4.5 \times 10^{19} \mathrm{~m}^{-3}, \mathrm{Z}_{\mathrm{eff}}=4.0$, and profile peakedness, 
$n_{e}(0) /<n_{e}>=2.4$. Measurements of $T_{e}(r, t)$ were made using ECE (Electron Cyclutron Emission) radiometry 6 (4 $\mathrm{msec}$ time resolution). A 10 channel infrared interferometer ${ }^{7}$ array was used to measure $\mathrm{n}_{\mathrm{e}}(\mathrm{r}, \mathrm{t})$ and to confirm poloidal symmetry of the injected helium into the edge plasma (transport parallel to the magnetic field is much faster than perpendicular transport). These line-integrated raw density data were A.bel inverted ${ }^{8}$ and smoothed (over $3 \mathrm{msec}$ ). TRANSP calculations with various time resolutions (2 to $10 \mathrm{msec}$ ) and numbers of Monte Carlo beam particles produced no significant changes in these results. The TRANSP calculated heat fluxes were smoothed in time over $10 \mathrm{msec}$.

The inference of convective heat transport dominance was previously demonstrated by using the equilibrium results from TRANSP calculated power balances. For electrons, this balance gives $Q_{e}$, the electron heat flux, subsequently separated into its conductive and convective parts:

$$
\mathrm{Q}_{\mathrm{e}}=-\mathrm{n}_{\mathrm{e}} \chi_{\mathrm{e}} \nabla \mathrm{T}_{\mathrm{e}}+(3 / 2) \mathrm{T}_{\mathrm{e}} \Gamma_{\mathrm{e}}
$$

where $T_{e}, n_{e}$, and $\chi_{e}$ are the electron temperature, density, and effective heat diffusion coefficient respectively. The quantity $\Gamma_{\mathrm{e}}$ is the electron particle flux calculated through TRANSP by a particle balance. The multiplier $3 / 2$ was chosen rather than $5 / 2$ in order to keep the effective ion heat diffusion coefficient positive in the supershot regime. ${ }^{2,4}$ It was observed for both ions and electrons that the quantity $2 \mathrm{Q} / 3 \mathrm{~T} \Gamma$ was greater than but close to unity which 
indicated that a large component of the heat transport was due to the convective term.

In this study, we used $\mathrm{He}$ gas puff induced perturbed electron quantities:

$$
\delta Q_{\text {total }}=\delta Q_{\text {conductive }}+\delta Q_{\text {convective }}
$$

where $\delta Q_{\text {convective }}=3 / 2 \delta\left(\mathrm{T}_{\mathrm{e}} \Gamma_{\mathrm{e}}\right) \approx 3 / 2 \mathrm{~T}_{\mathrm{e}} \delta \Gamma_{\mathrm{e}}$ is observed. Any

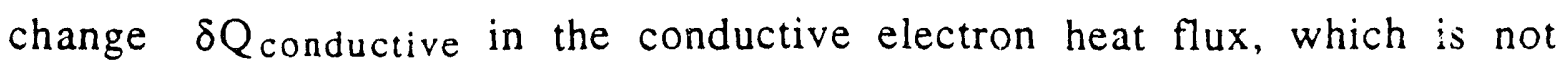
assumed to have a specific form as in Eq. 1, is imperceptible above the approximately $10 \%$ relative noise level in the fluxes coming from the Monte Carlo energy source (beam) calculations both inside and outside of the core. In fact, near the plasma core, the only reliable $\delta Q_{\text {total }}$ measurement results from $\delta Q_{\text {convective }}$ (see Figure 1). The induced $\delta Q_{\text {total }} \approx \delta Q_{\text {convective }}$ and needs to be of a larger magnitude than $10 \%\left(Q_{\text {total }}\right)$ in order to be observed. This happens in the core region where convective heat transport is dominant such that the

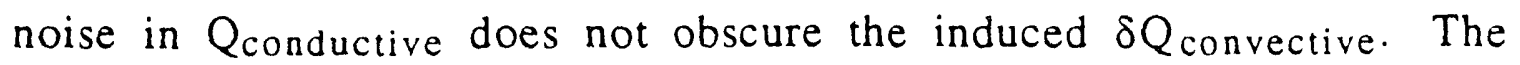

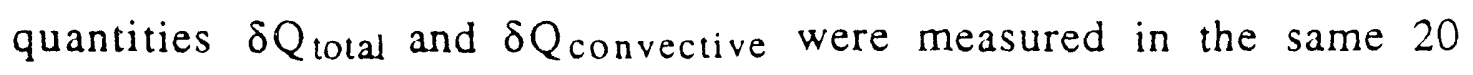
msec time window (4.05s to $4.07 \mathrm{~s}$ in the core region) within the initial perturbation. This time window was chosen such that the noise in $\delta Q$ conductive was at a minimum and there was simultaneously a large negative drop in $\delta Q_{\text {convective concurrent with }}$ the local initial rise of the electron density.

It should also be noted that the strange shape of this perturbation for a single gas puff is still not yet understood. Specifically, the observed and expected transient drop in $\delta Q$ convective in response to 
the locally initial increase in electron density seems to be superimposed on a longer time transient rise occurring in all three heat fluxes (see $r=0.15 \mathrm{~m}$ of Figure 1). Supershot plasmas are observed to be very dynamic (large gradients in density and temperature and heavily driven by beams) ${ }^{\prime}$ which could be responsible for small flux surface movements that would affect both the conductive and convective heat flux components similarly and result in the strange transient rise mentioned above. The small gas puff did not seem to have a significant effect on the plasma globally: magnetics diagnostics, which are sensitive to the plasma edge where the largest induced perturbations occur, show $\delta \mathrm{R}_{0}, \delta \mathrm{a}<1.5 \mathrm{~cm}, \delta \mathrm{I}_{\mathrm{p}}<$ $3 \%$, and $\delta q_{a}<1 \%$. It should be stressed, however, that fundamentally our major observation is that a clearly significant and induced $\delta Q$ convective occurs unaccompanied by a significant or induced Qconductive perturbation between $4.05 \mathrm{~s}$ and $4.10 \mathrm{~s}$ in the core region (see Figure 1). The degree to which this exclusively convective heat flux perturbation gets expressed in the power balance (or total heat flux) is the basic measurement here.

The electron particle flux changes by factors of about $30-50 \%$ due to the perturbation, but the total electron heat flux follows the dynamics of the particle flux only in the core of supershot plasmas. Essentially, this large response of the particle flux to the small gas puff locally increasing the electron density $\left(\delta \mathrm{n}_{\mathrm{e}} / \mathrm{n}_{\mathrm{e}} \approx+6 \%\right)$ is in contrast to the negligible conductive heat flux response. From a localized transient perturbation in which the scale length of the perturbation is much smaller than the equilibrium scale length, the following is expected and observed: 


$$
\frac{\delta \nabla 2 n_{\mathrm{e}}}{\nabla^{2} \mathrm{n}_{\mathrm{e}}} \gg \frac{\delta \nabla \mathrm{n}_{\mathrm{e}}}{\nabla \mathrm{n}_{\mathrm{e}}} \gg \frac{\delta \mathrm{n}_{\mathrm{e}}}{\mathrm{n}_{\mathrm{e}}}
$$

where the inequalities represent factors of about six. The relative electron temperature perturbation is $<2 \%$ and its gradient changes are likewise negligible relative to the large changes in the electron density gradient. This provides for a good indication from this transient method of the convective heat flux dominance.

This perturbed convective dominance can be quantified by forming the following ratio $\mathrm{R}$ of perturbations (see Figure 2):

$$
R=\delta Q_{\text {total }} / \delta Q_{\text {convective }}
$$

The ratio $R$ increases with minor radius and approaches unity near the plasma center, or equivalently, the ratio $\delta Q_{\text {total }} / T_{\mathrm{e}} \delta \Gamma_{\mathrm{e}}$ approaches $3 / 2$ near the plasma center. The estimated uncertainty in $R$ does not include uncertainty in the convective multiplier (i.e., $3 / 2$ vs. 5/2) which was set at $3 / 2$. This perturbed measurement has the advantage of not involving source calculations since the beam deposition of particles and energy were not perturbed as a result of the puff. However, possible anomalous electron-ion heat exchange processes have not been considered. Classical electron-ion heat exchange perturbations were not observed in the TRANSP output on these time scales and were small as expected since they are perturbed source terms that respond to $\delta \mathrm{n}_{\mathrm{e}}$ and not $\delta \nabla \mathrm{n}_{\mathrm{e}}$ (see Eq. 3) and can only significantly affect the longer time behavior of the perturbations. 


\section{Discussion}

In considering the possible implications of these results (Fig. 2), it is important to realize that the formal definitions of "conductive" and "convective" are blurred especially in the case of turbulence. In the context of electrostatic microinstabiiity theories, $2 \mathrm{Q} / 3 \mathrm{~T} \Gamma$ approaching unity is really a measure of the dominance of drives other than $\nabla \mathrm{T}$ that link $\Gamma$ and $Q$. In these supershots, there is a sharp decrease in $\eta_{i}$ at $\mathrm{r} \approx 0.40 \mathrm{~m}$. to a value below $\eta_{\mathrm{i}}$ crit $\approx 1.5$ for $\mathrm{r}<0.30 \mathrm{~m}$ ( $\eta_{\mathrm{e}}<1.0$ for $r<0.30 \mathrm{~m})$. This is qualitatively consistent with the supershot not being dominated by $\nabla \mathrm{T}$-driven modes in the core region. In the region $r>0.40 \mathrm{~m}, \eta_{i}>>\eta_{i}$ crit which is qualitatively consistent with the dominance of $\nabla \mathrm{T}$-driven modes ${ }^{9}$ in the outer regions of supershots. However, perturbations in $\eta_{i}$ (through $\mathrm{dn}_{\mathrm{i}} / \mathrm{dr}$ but not $\mathrm{dT}_{\mathrm{i}} / \mathrm{dr}$ ) in L-mode plasmas in TFTR produced no change in the local heat transport, 10 in apparent contradiction with such an interpretation.

Results from this study are apparently in contradiction to critical electron temperature gradient conductive models 11 which seem to break down in the convectively dominated supershot core. These models assume that the conductive electron heat flux is proportional to the difference between $\nabla \mathrm{T}_{\mathrm{e}}$ and some $\left(\nabla \mathrm{T}_{\mathrm{e}}\right)_{\text {critical. Calculations }}{ }^{2}$ using a typical form ${ }^{11}$ of $\left(\nabla \mathrm{T}_{\mathrm{e}}\right)_{\text {critical }}$ show that it is significantly smaller than $\nabla \mathrm{T}_{\mathrm{e}}$. This magnitude difference implies a larger conductive component to the electron heat flux than is actually observed in the supershot core. 
Also potentially relevant are some theories of nonlinear thermodynamics 13,14 which predict a correlation between driver power and transport near the stationary states of conductively dominated nonlinear systems. The facts that supershot transport is independent of auxiliary power and that supershots have a convectively dominated core, in this context, is qualitatively consistent with the supershot being a departure from an L-mode "stationary state."

\section{Summary}

Perturbation techniques provide an alternative method to power balance approaches for inferring the relative amount of convective heat transport. In particular, these small gas puffs produced mainly particle flux perturbations without perturbing any heat source terms, the beam fueling, or the conductive heat flux. Therefore, when the perturbed heat flux is proportional to the perturbed particle flux, the relative amount of convective heat transport can be directly demonstrated. As shown in Fig. 2, convective heat transport dominates the perturbed heat flux response in the core of supershot plasmas in TFTR.

The evolution from L-mode to supershot is continuous and strongly correlated to the peakedness in the density profile ${ }^{2}$ which results from the primary particle source from intense neutral beam injection being in the core rather than from recycling at the plasma edge. Results from this short study and others in the past suggest that another distinguishing feature between L-mode and supershot confinement is the degree of dominance of convective heat transport 
in the plasma core. In fact, in similar L-mode plasmas with these same gas puffs, we can measure no direct correspondence between $\delta Q_{\text {total }}$ and $\delta \Gamma$ which would be needed to form the ratio, $R$, in Eq. (4).

This indicates that, in contrast to supershots, L-mode plasmas are dominated by heat conduction throughout the plasma. Theories which predict separate transport drives for the core versus the rest of the supershot plasma would seem to be in better agreement with these results than theories which consider only a single transport drive throughout.

\section{A cknowledgements}

The authors gratefully acknowledge the help of W. M. Tang for discussions of microinstabilities, D. R. Mikkelsen for critical temperature gradient calculations, M. C. Zarnstorff, S. D. Scott, R. M. Wieland, and many others in the TFTR Physics group. This research was supported by TFTR United States Department of Energy contract DE-AC02-76-CHO-3073 and United States Department of Energy grant DE-FG02-92ER54139. 


\section{References:}

IR. J. Hawryluk, V. Arunasalam, M. G. Bell, M. Bitter, W. R. Blanchard, N. L. Bretz, R. Budny, C. E. Bush, J. D. Callen, S. A. Cohen, S. K. Combs, S. L. Davis, D. L. Dimock. H. F. Dylla, P. C. Efthimion, L. C. Emerson, A. C. England, H. P. Eubank, R. J. Fonck, E. Fredrickson, H. P. Furth, G. Gammel, R. J. Goldston, B. Grek, L. R. Grisham, G. Hammet, W. W. Heidbrink, H. W. Hendel, K. W. Hill, E. Ainnov, S. Hiroe, H. Hsuan, R. A. Hulse, K. P. Jaehnig, D. Jassby, F. C. Jobes, D. W. Johnson, L. C. Johnson, R. Kaita, R. Kamperschruer, S. M. Kaye, S. J.

Kilpatrick, R. J. Knize, H. Kugel, P. H. LaMarche, B. LeBlanc, R. Little, C. H. Ma, D. 'A. Manos, D. K. Mansfield, R. T. McCann, M. P. McCarthy, D. C. McCune, K. McGuire, D. H. McNeill, D. M. Meade, S. S. Medley, D. R. Mikkelsen, S. L. Milora. W. Morris, D. Mueller, V. Mukhovatov, E. B. Nieschmidt, J. O'Rourke, D. K. Owens, H. Park, N. Pomphrey, B. Prichard, A. T. Ramsey, M. H. Redi, A. L. Roquemore, P. H. Rutherford, N. R. Sauthoff, G. Schilling, J. Schivell, G. L. Schmidt, S. D. Scott, S. Sesnic, J. C. Sinnis, F. J. Stauffer, B. C. Stratton, ,G. D. Tait, G. Taylor, J. R. Timberlake, H. H. Towner. M. Ulrickson, V. Vershkov, S. Von Goeler, F. Wagner, R. Weiland, J. B. Wilgen, M. Williams, K. L. Wong, S. Yoshikawa, R. Yoshino, K. M. Young, M. C. Zarnstorff, V. S. Zaveryaev, S. J. Zweben, in Plasma Physics and Controlled Nuclear Fusion Research.

Proceedings of the 11 th International Conference, held in Kyoto, Japan, 1986. (International Atomic Energy Agency, Vienna, 1987). Vol. 1, p. 51. 
${ }^{2}$ M. C. Zarnstorff, V. Arunasalam, C. W. Barnes, M. G. Bell, M. Bitter, H.-S. Bosch, N. L. Bretz, R Budny, C. E. Bush, A. Cavallo, T. K. Chu, S. A Cohen, P. L. Colestock, S. L. Davis, D. L. Dimock, H. F. Dylla, P. C. Efthimion, A. B. Ehrhardt, R. J. Fonck, E. D. Fredrickson, H. P. Furth, G. Gammel, R. J. Goldston, G. J. Greene, B. Grek, L. R. Grisham, G. W. Hammett, R. J. Hawryluk, H. W. Hendel, K. W. Hill, E. Hinnov, J. C. Hosea, R. B. Howell, H. Hsuan, R. A. Hulse, K. P. Jaehnig, A. C. Janos, D. L. Jassby, F. C. Jobes, D. W. Johnson, L. C. Johnson, R. Kaita, C. Kieras-Phillips, S. J. Kilpatrick, V. A. Krupin, P. H. LaMarche, B. LeBlanc, R. Little, A. I. Lysojvan, D. M. Manos, D. K. Mansfield, E. Mazzucato, R. T. McCann, M. P. McCarthy, D. C. McCune, K. M. McGuire, D. H. McNeill, D. M. Meade, S. S. Medley, D. R. Mikkelsen, R. W. Motley, D. Mueller, Y. Murakami, J. A. Murphy, E. B. Nieschmidt, D. K. Owens, H. K. Park, A. T. Ramsey, M. H. Redi, A. L. Roquemore, P. H. Rutherford, T. Saito, N. R. Sauthoff, G. Schilling, J. schivell, G. L. Schmidt, S. D. Scott, J. C. Sinnis, J. E. Stevens, W. Stodiek, J. D. Strachan, B. C. Stratton, G. D. Tait, G. Taylor, J. R. Timberlake, H. H. Towner, M. Ulrickson, S. Von Goeler, R. M. Wieland, M. D. Williams, J. R. Wilson, K.-L. Wong, S. Yoshikawa, K. M. Young, S. J. Zweben, in Plasma Physics and Controlled Nuclear Fusion Research, Proceedings of the 12 th International Conference held in Nice. France, 1988 (International Atomic Energy Agency, Vienna, 1989), Vol. 1, p. 183.

${ }^{3}$ P. C. Efthimion, C. W. Barnes, M. G. Bell, H. Biglari, N. Bretz, P. H. Daimond, G. Hammett, W. Heidbrink, R. Hulse, D. Johnson, Y. Kusama, D. Mansfield, S. S. Medley, R. Nazikian, H. Park, A. Ramsey, G. Rewoldt, S. D. Scott, B. C. Stratton, E. Synakowski, W. M. Tang, G. Taylor, M. C. Zarnstorff, Phys. of Fluids B 3, 2315 (1991). 
${ }^{4}$ M. C. Zarnstorff, M. G. Bell, M. Bitter, C. Bush, R. J. Fonck, R. J. Goldston, B. Grek, R. J. Hawryluk, K. Hill, B. Howell, K. Jaehnig, D. Johnson, R. Knize, K. McGuire, A. Ramsey, G. Schilling, J. Schivell, S. D. Scott, G. Taylor, in Controlled Fusion and Plasma Heating. Proceedings of the 15th European Conference held in Dubrovnik, Yugoslavia, 1988 (Europian Physical Society, 1988), Vol. 12B, pt. 1, p.95.

5R. J. Goldston, D. C. McCune, H. H. Towner, S. L. Davis, R. J. Hawryluk, G. L. Schmidt, Journal of Comput. Phys. 43, 61 (1981).

${ }^{6}$ G. Taylor, P. Efthimion, M. McCarthy, V. Arunasalam, R. Bitzer, J. Bryer, R. Cutler, E. Fredd, M. A. Goldman, D. Kaufman, Rev. Sci. Instrum. 55, 1739 (1984).

${ }^{7}$ D. K. Mansfield, H. K. Park, L. C. Johnson, H. M. Anderson, R. Chouinard, V. S. Foote, C. H. Ma, B. J. Clifton, Applied Optics 26, 4469 (1987).

${ }^{8}$ H. K. Park, Plasma Phys. and Controlled Fusion 31, 2035 (1989).

${ }^{9}$ G. Rewoldt, W. M. Tang, Phys. Fluids B 2, 318 (1990). 
10 M. C. Zarnstorf, C. W. Barnes, P. C. Efthimion, G. W. Hammett, W. Horton, R. A. Hulse, D. K. Mansfield, E. S. Marmar, K. M. McGuire, G. Rewoldt, B. C. Stratton, E. J. Syrakowski, W. M. Tang, J. L. Terry, X. Q. Xu, M. G. Bell, M. Bitter, N. L. Bretz, R. Budny, C. E. Bush, P. H. Diamond, R. J. Fonck, E. D. Fredrickson, H. P. Furth, R. J. Goldston, B. Grek, R. J. Hawryluk, K. W. Hill, H. Hsuan, D. W. Johnson, D. C. McCune, D. M. Meade, D. Mueller, D. K. Owens, H. K. Park, A. T. Ramsey, M. N. Rosenbluth. J. Schivell, G. L. Schmidt, S. D. Scott, G. Taylor, R. M. Weiland, in Plasma Physics and Controlled Nuclear Fusion Research, Proceedings of the 13 th International Conference, held in Washington, D.C., United States of America, 1990 (International Atomic Energy Agency, Vienna, 1991), Vol. 1, p. 109.

${ }^{11}$ P.-H. Rebut, M. L. Watkins, D. L. Gambier, D. Boucher, Phys. Fluids B 3, 2209 (1991).

12D. R. Mikkelsen (private communication, 1992).

133. H. Lavenda, Phys. Rev. A 9, 929 (1974).

${ }^{14}$ B. H. Lavenda, Thermodynamics of Irreversible Processes (Wiley, New York. 1978). 


\section{Eigure Captions:}

FIG. 1 Representative measurements of $\delta Q_{\text {total }}$ and

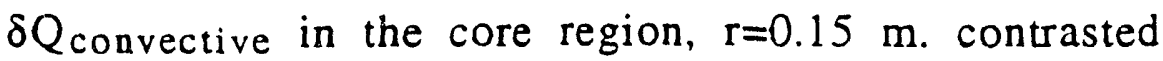
with the outer region, $r=0.45 \mathrm{~m}$. In the outer region, no reliable measurement of $\delta Q_{\text {total }}$ is possible due to the strong conductive dominance there. Note the

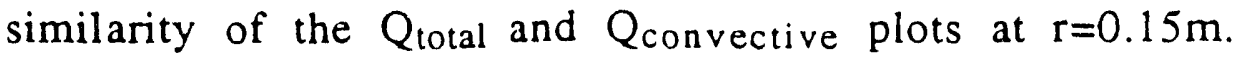
and the similarity of the $Q_{\text {total }}$ and $Q_{\text {conductive plots at }}$ $r=0.45 \mathrm{~m}$. (TFTR shots $49855-49860$ )

FIG. 2. The ratio, $R$ in Eq. (3), of perturbed heat flux components, $\delta Q_{\text {total }} / \delta Q_{\text {convective, approaches unity }}$ in the core region of a supershot ensemble. Beyond $\mathrm{r}=0.40 \mathrm{~m}, \delta \mathrm{Q}_{\text {total }}$ seems unresponsive to $\delta \mathrm{Q}_{\text {convective, }}$ indicating dominance by the conductive heat flux there. Inside $\mathrm{r}=0.30 \mathrm{~m}, \delta \mathrm{Q}_{\text {total }} / \delta \mathrm{Q}_{\text {convective }}<2$, indicating convective dominance. 
Figure 1

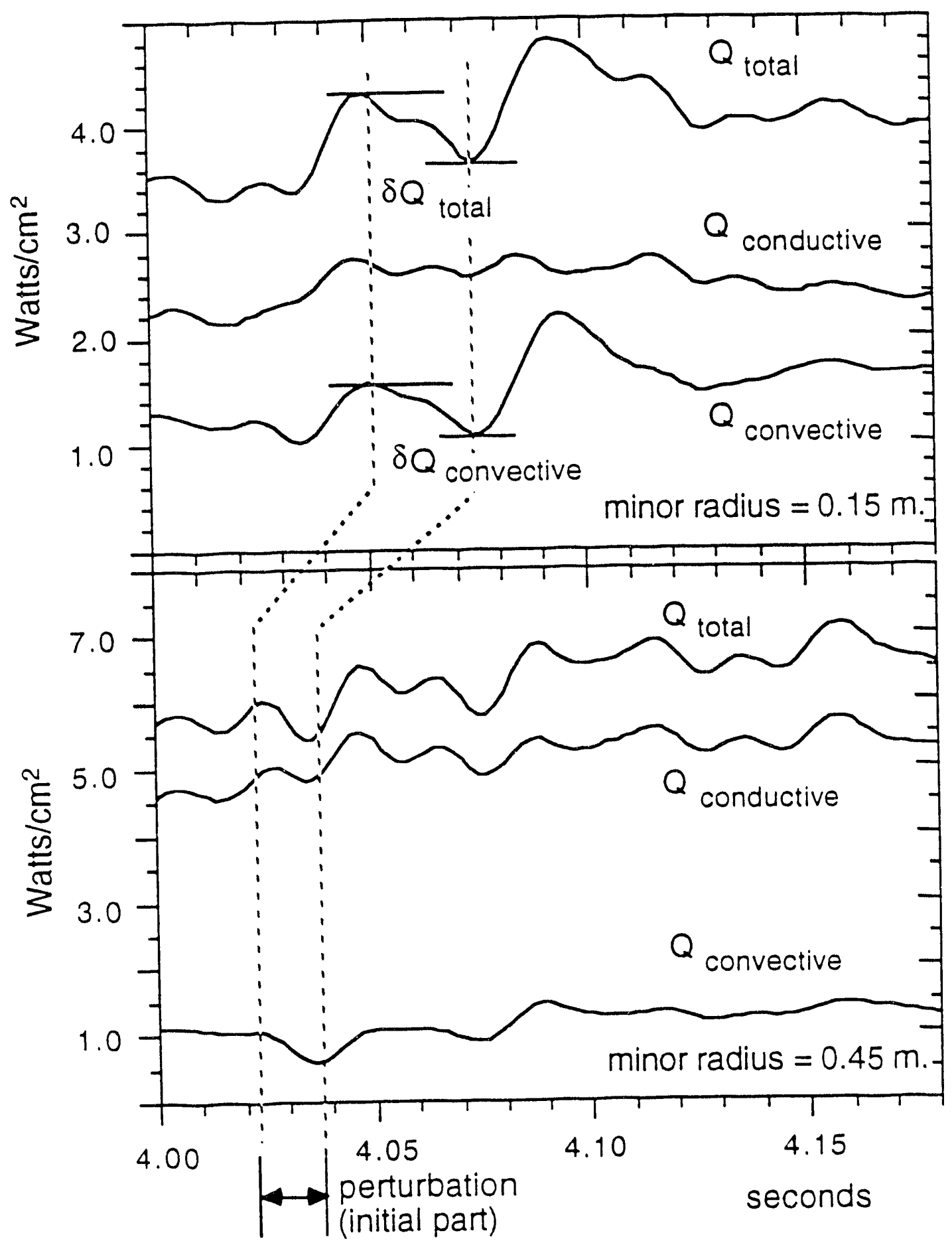


Figure 2

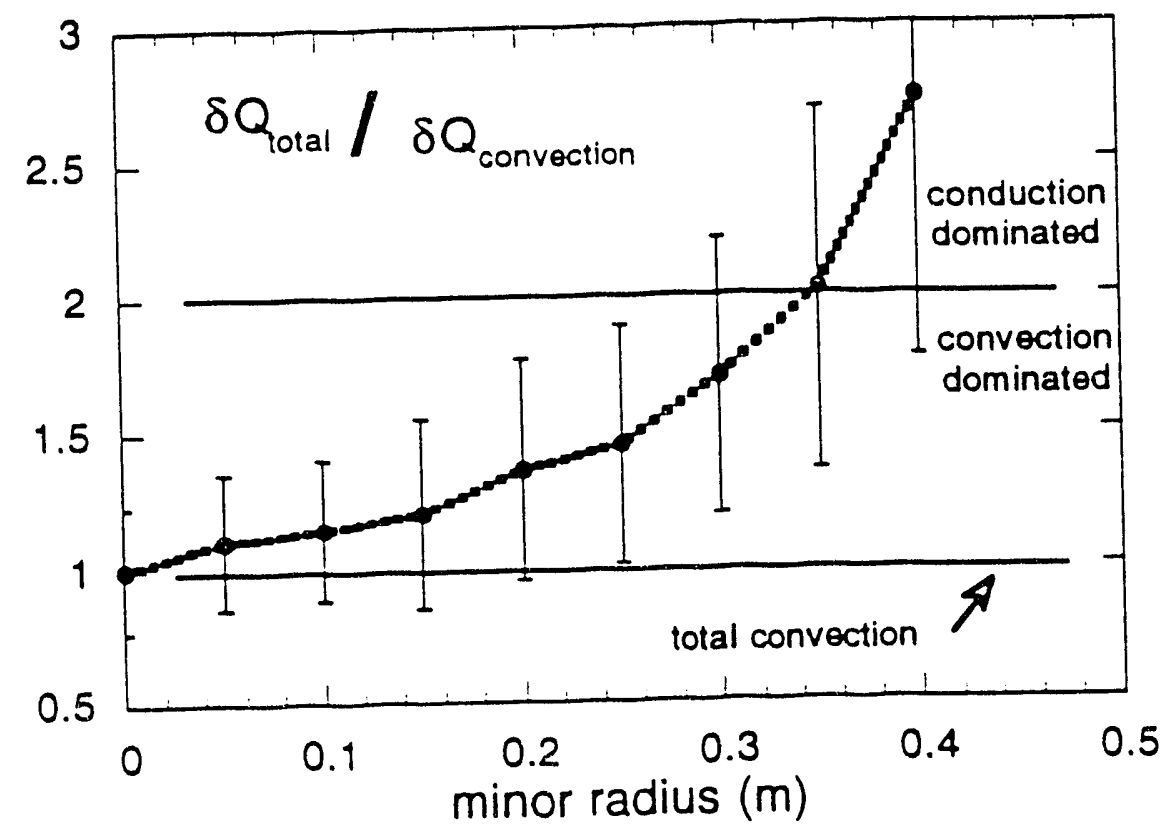


Dr. F. Proton, Unw of Woltongong, AUSTRALIA

Prof. M.H. Brennan. Univ. of Sydney, AUSTRALIA

Plasma Researth Lab.. Australian Nat Univ. AUSTRALIA

Prot: R. Jones, Finders Univ, AUSTRALIA

Prot. F. Cap, Inst for Theoretical Physics, AUSTRIA

Prot. M. Heinder, Insuaut tur Theorebische Physik, AUSTRIA

Prot. M. Goossens. Astronomisch Instiuut, BELGIUM Ecole Royale Militaire, Lab. de Pry. Plasmas, BELGiUM Commission-Eurapean, DG. XII-Fusion Prog.. BELGIUM Prof. R. Bouciaud, Rijksuniversion Gont BELGIUM Dr. P.H. Sakanaka, Instutro Frica, BRAZIL Instruto Neciond De Porquieas Especiaic-INPE, BRAZIL Documents Otfico, Abrnic Enorgy of Canada LUd., CANADA Dr. M.P. Bactynski, MPB Tochnotogios, Inc., CANADA Dr. H.M. Skarsgard, Univ. Ol Sackatchowan, CANADA Prof. J. Toictmam, Unn. of Montreal, CANADA Prol. S.R. Sroenivasan, Univ. of Caggary, CANADA Prof. T.W. Johnston, INRS-Energie, CANADA Dr. R. Botion, Contro canadion de tusion magnéviqu, CANADA Dr. C.R. James., Univ. of Alborta, CANADA Dr. P. Lukác, Kormonsketho Universzita, CZECHOSLOVAKIA The Libranan, Cuham Laborabory, ENGLAND Library. A61, Ruthortord Applown Laboratory, ENGLAND Mrs. S.A. Hutchinson, JET Libray, ENGLAND Dr S.C. Shama Unir. of South Pacific, FIJI ISLANDS $P$. Mathonen, Univ. of Helsinki, FINLAND Prot M.N. Bussac. Eco Poly chnique., FRANCE C. Mourtor, Lab. de Physique dos Miliaux lonisés. FRANCE J. Radel CENCADARACHE - Bat 506, FRANCE Prot E. Economow. Univ of Crote, GREECE Ms. C Rinni. Unn of loamina, GREECE Dr. T Mua, Acadomy Bibtiographic Sor., HONG KONG Prepnnt Libray. Hunganan Academy of Sai. HUNGARY Dr. 8 Das Gupta. Saha inst of Nuciear Ptryscos, INDIA Dr. P. Kaw, Inst. for Plasma Rosoarch, INDIA Dr. P. Rosenas, Israt Inst of Tectinotogy, ISPAEL Libranan, Inmational Conter for Theo Physics. ITALY Miss C De Palo. Assocazione EURATOAHENEA, ITALY Dr. G. Grosso, is jut to d Fisica del Plasma. ITALY Prot G Rostangni, is tuturo Gas tonizzad Del Cnr, ITALY Dr. H. Yamato. Toshiba Res is Dovet Center, JAPAN
Prot. 1. Kawakami, Hroshwna Univ., JAPAN

Prol. K. Nishikawa, Hiroshima Univ., JAPAN

Director, Japan Alomic Enorgy Research Inst, JAPAN

Prot. S. Iroh, Kyustou Univ.. JAPAN

Research Into. Ct., National Instit for Fusion Science. JAPAN

Prof. S. Tanaka, Kyoto Univ., JAPAN

Library, Kyow Univ., JAPAN

Prot. N. Inowe, Univ. of Tokyo, JAPAN

Soctotary, Plasma Section, Eloctoroctinical Lab., JAPAN

S. Mori, Tecthical Advisor, JAERI, JAPAN

Dr. O. Mitarai, Kumamow inst of Technotogy. JAPAN

J. Hyoon-Sook, Kores Abomic Energy Research Inst, KOAEA

D.I. Chai, The Korea Adv. Inst of Sai. \& Tech., KOREA

Prot. B.S. Litey, Univ. of Waikato, NEW ZEALAND

Inst of Physics. Chinese Acad Sa PEOPLE'S REP. OF CHINA

Lorary, Inst of Plasma Physics, PEOPLE'S REP. OF CHINA

Tsinghua Unir. Library, PEOPLE'S REPUBLIC OF CHINA

$Z$ L. S.W. Inst Physios, PEOPLE'S REPUBUC OF CHINA

Prol. J.A.C. Cabred, Instituto Suporior Tecrico, PORTUGAL

Dr. O. Potrus, AL I CUZA Univ., ROMANIA

Dr. J. de Villiers, Fusion Studies, AEC, S. AFRICA

Prof. M.A. Hellberg, Univ. of Nazal, S. AFRICA

Prot. D.E. Kum, Pohang Inst. of Sci. \& Tech., SO KOREA

Prot. C.I.E.M.A.T, Fusion Division Library, SPAIN

Dr. L SEntio, Univ. of UMEA, SWEDEN

Lorary, Royal Inst of Tectnology, SWEDEN

Prof. H. Wihemson, Chaimers Univ of Tech, SWEDEN

Contro Phys. Des Plasmas, Ecole Polytoch, SWITZERLAND Bibliotrak, Inst. Voor Plasma-Fysica, THE NETHERLANDS Asst Prot. Dr. S. Cakx, Midde Easi Tech. Univ. TURKEY Dr. V.A. Gulthith, Sa. Ros. Inst Eloctrophys.I Apparatus. USSR

Or. D.D. Fyurov, Siberian Branch of Academy of Sa., USSR

D. G.A. Elisor. I.V. Kurctatov Inst. USSA

Librarian. The Ukr.SSR Acadorny of Scrences. USSR

Dr. LM. Korrizinnykh, Inst. of General Physics, USSR

Kemtorsctungsanlage GmbH, Zentralbibliothok, W. GERMANY

Bibliothok, Inst Fü Plasmatorschung. W GERMANY

Prof. K. Sctinder, Ruhr. Universitat Boctium. W GERMANY

Dr. F. Wagner, (ASDEX), Max.Planck-Instutut. W GERMANY

Loranan, Max-Plendk-Insutur, W GERMANY

Prol. R.K. Janer. Inst of Ptysics, YUGOSLAVIA 

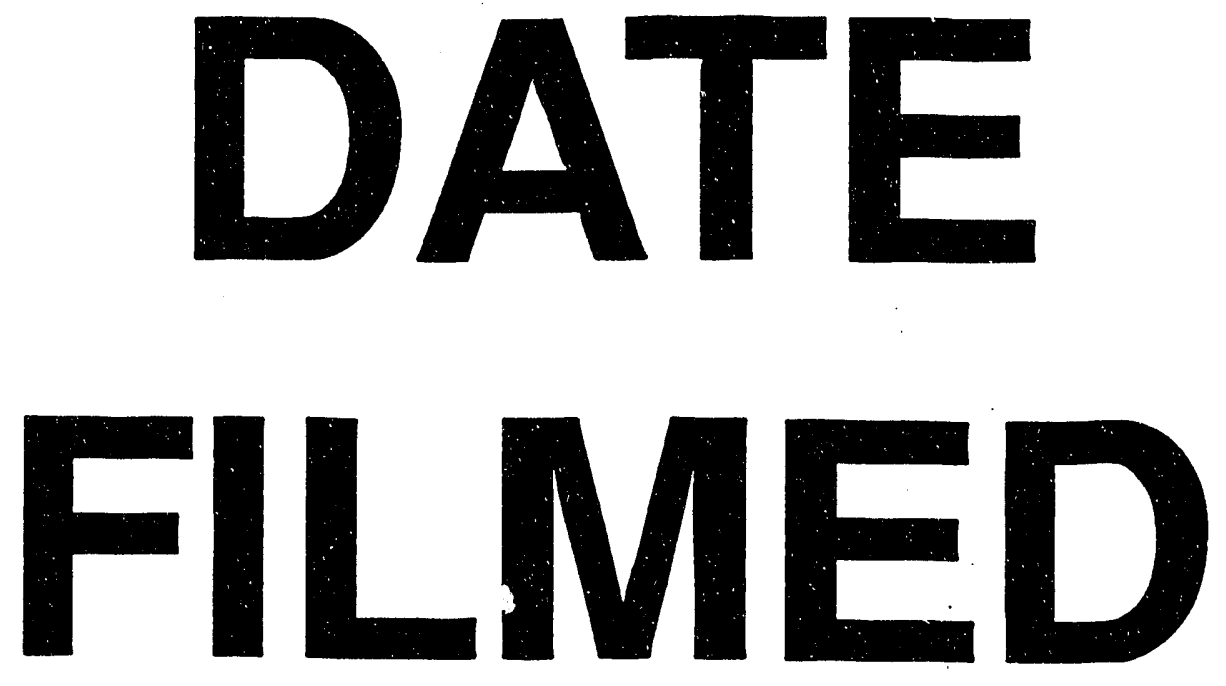

$11 / 12 / 93$
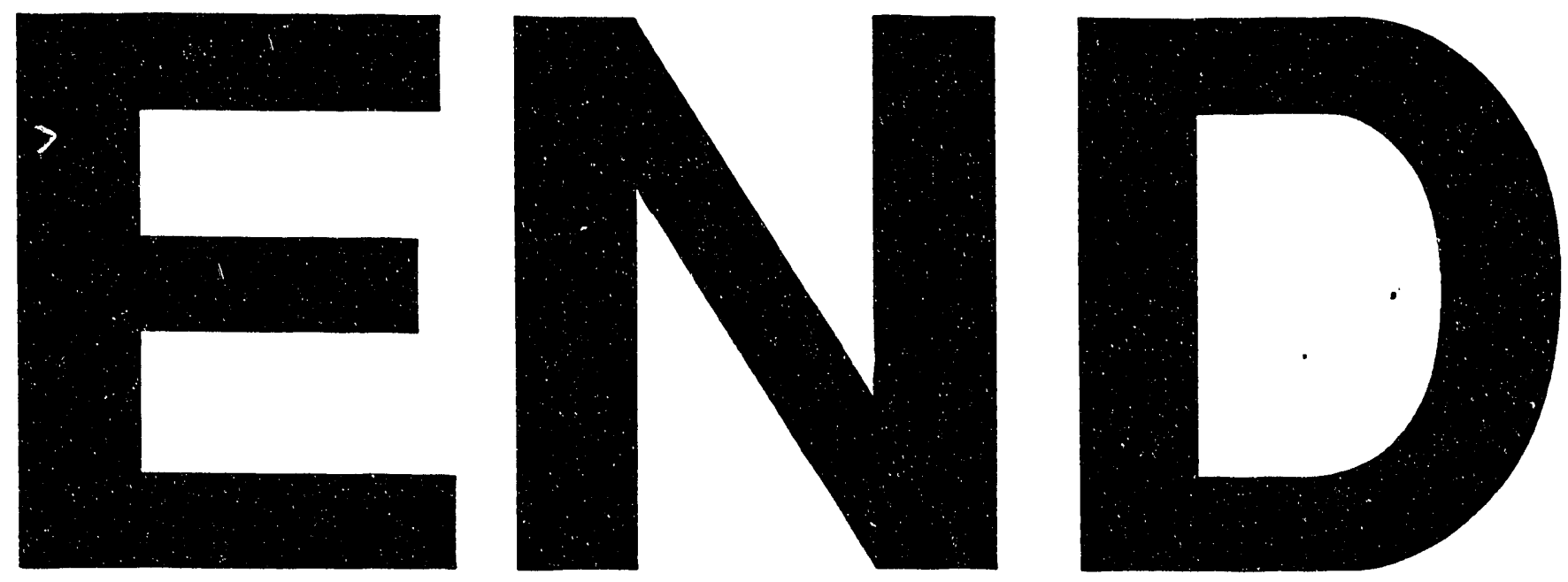
